\title{
David Whyte: Ecocide: Kill the Corporation Before It Kills Us
}

\author{
Manchester University Press, Manchester, UK, 2020, xvi + 222 pp, ISBN: \\ 978-1-5261-4698-4 (PB)
}

\section{Rob White ${ }^{1}$}

Published online: 23 July 2021

(c) The Author(s), under exclusive licence to Springer Nature B.V. 2021, corrected publication 2021

The environmental situation of the world today is dire.

As I write this, record temperatures burn the west coast of North America, while tornadoes churn their way through a wetter than normal east coast of the same continent. Our oceans are warming, sea-level rise is accelerating, glaciers and the vast Antarctic ice sheet are melting, and mainland freshwater is diminishing everywhere. The past six years, including 2020, have been the six warmest years on record.

Meanwhile, more than one million animal and plant species are now threatened with extinction, many within decades, and more than ever before in human history.

The outlook does not look good. And that is without even considering the extent and geographical reach of air, land and water pollution that is devastating the planet. For example, the impact of plastics in oceans is only the tip of the rapidly melting iceberg. Environmental collapse is occurring on many different fronts, and time is rapidly running out to prevent ecocide on a grand scale.

\section{Corporations and Capitalism are the Problem}

Corporations are the main culprits that are systematically killing our planet. Why and how this is the case has long been the focus of those examining the contours and consequences of corporate and white-collar crime. David Whyte's book, Ecocide: Kill the Corporation Before It Kills Us (2020), provides one of the best and most definitive analyses of precisely this phenomenon.

Whyte also criticizes approaches to environmental crises that bend back to the key instigators of the problem. Consider his observation in regards threats to our environment: "Yet in the international treaties, and in many of the radical proposals to transform our economy, corporations are either envisaged as a solution to the crisis, or are ignored completely" (Whyte 2020: 9). This also translates into the false promise that corporations can be "partners," engage in "dialog," and be part of the "answer" to our global environmental problems.

Rob White

r.d.white@utas.edu.au

1 School of Social Sciences, University of Tasmania, Hobart, TAS, Australia 
According to Whyte, this is not possible given the mandate and track record of corporations. For him, the corporation minimizes the chances of any outcome other than the destruction of the natural environment because it dehumanizes social relationships, thereby guaranteeing indifference to human suffering and environmental degradation. In social construction and in effect, the corporation is designed — and licensed — to kill.

The state is instrumental in this task - by setting the institutional rules, largely ignoring corporate-generated harm, and colluding directly in profit-enhancing but planet-destroying activities. This occurs wherever the corporate form is dominant and capitalism is entrenched. In other words, it happens everywhere. This is a current trend, not simply past practice.

For example, consider the following. The International Energy Agency (IEA) (2021) argued recently that the energy sector holds the key to averting the worst effects of climate change by following a net zero pathway built on renewables. According to the IEA, in order to reach a vital milestone on this pathway, there should be no new oil and gas fields approved and no new coal mines or mine extensions.

Yet, "Global fossil fuel consumption subsidies increased by $50 \%$ over the past 3 years, reaching a peak of almost US\$430 billion in 2018" (Watts et al. 2019: 1836). In Australia, a 2021 report found that "Every year Australian governments provide subsidies worth billions to fossil fuel producers and major users.... [T] hese subsidies cost state, territory and federal governments in Australia \$10.3 billion in 2020-21" (Campbell et al. 2021: 10).

Meanwhile, on the day of the release of the IEA report, the Australian government announced that it would spend up to AUS\$600 million building a new gas-fired power station in New South Wales, with the owners of the Tomago aluminum smelter, including Rio Tinto, the main beneficiary (Tingle 2020). All of this is not surprising, given that the national coronavirus economic recovery committee is stacked with business leaders from the fossil fuel industries, and gas in particular (Morgan and Long 2020).

A key defining feature of ecocide is that such crimes involve acts and omissions that are socially harmful and carried out by elites and/or those who wield significant political and social authority in the sectors or domains of their influence. Powerful social interests not only perpetuate great harms (and benefit from them), but they also obscure and mask the nature of harm production. They are also best placed to resist the criminalization process, more generally.

\section{Centrality of Politics}

All of this leads to the centrality of politics in discussions about "what is to be done" about corporations. Whyte (2020: 125) points out that:

the rate of the political economy of speed matters. It matters because governments can and do generally intervene in ways that regulate the speed of production, distribution and consumption. Indeed, this is the importance of the political sphere. The rate at which we are destroying the planet is regulated by a process that is still largely determined by politics.

Solutions to environmental degradation that rely on corporations (a form of "green capitalism") quickly take us down the cul-de-sac of continued growth. Ecocide as business opportunity diverts us even further from actually tackling its causes. 
As Whyte (2020) emphasizes, the political starting point is intervention against corporations. Challenging corporate power involves different strategies. These include sequestration of the assets of those companies responsible for global carbon production and placing these under public control. They include breaking corporate power by preventing cross-ownership, ending the impunity for investors and shareholders, and issuing "equity fines" that re-socialize business by transferring shares to workers and/or the community.

Environmental harm on a global scale demands responses that address the key underlying issues contributing to social and environmental injustice. Preventing ecocide means resisting and transforming the status quo. Time and space for "business as usual" must be radically and urgently diminished if social and ecological justice is to be achieved.

Fundamentally, this is about democracy, social need and the public interest. This is highlighted by the fact that we know from the science what the problem is and how to contain global warming. The political challenge is how to get there.

From my perspective, the key problem is that capitalism is an authoritarian economic system-one where the privatized control and appropriation of socialized production is imposed from above. This authoritarianism is grounded in private ownership of the means of production (a small number get to decide what is produced, how, and for whom), and it is evident in greater inequality (the huge disparities between the billionaires at the top and the rest of us) and in the intensified exploitation of nature and humans (paradoxically, because profit rates are threatened due to low wages and scarcity of natural resources).

Challenging capitalism can, therefore, be achieved only through the full socialization of the corporate enterprise and by greater democratization of our social institutions. This, in turn, leads us to reconsider the nature and role of the state.

In advanced economies, the state carries an economic weight comparable to or exceeding that of even the largest transnational corporations. The enduring centrality of the state is particularly evident in conditions of crisis (such as the global financial crisis and the COVID-19 pandemic). To ensure that production is for social need, however, we need the state to be "our" state. And for this, we need transformational nationalization (van der Velden and White 2021). This refers to the state taking command of the central levers of the economy-taking the private capital that owns and controls these levers and putting them into public hands.

This form of nationalization incorporates "nation building" (such as infrastructure projects) and "socialization" of essential industries and services (such as finance, housing and manufacturing). Decisions about the crucial pillars of social life-air, energy, food, shelter, security, water - are too important to be left in private hands (the billionaires) or secretive states (information controlling bureaucrats and self-serving politicians): governance must be public, open, cooperative and democratic.

Central to transformation is securing the core fundamentals of social life, in particular, the food retail giants and distribution networks, water and energy companies, and finance capital within the housing sector, including large property developers and landlords. As environmental activists might put it, the four elements - earth, air, water and sun (energy) - constitute "the commons" that needs to be placed into democratic hands.

The equation is simple: you cannot achieve transformation without fundamentally changing the ownership structure of the present political economy.

\section{References}

Campbell, R., Littleton, E., \& Armistead, A. (2021). Fossil Fuel Subsidies in Australia: Federal and state government assistance to fossil fuel producers and major users 2020-21. Canberra, ACT: The 
Australia Institute. Retrieved on June 30, 2021, from https://apo.org.au/sites/default/files/resourcefiles//apo-nid311955.pdf.

International Energy Agency. (2021). Net Zero by 2050: A Roadmap for the Global Energy Sector. Paris: IEA. Retrieved on July 19, 2021, from https://www.iea.org/reports/net-zero-by-2050.

Morgan, E., \& Long. S. (2020). Coronavirus economic recovery committee looks set to push Australia towards a gas-fired future. ABC News, May 12 (updated May 27). Retrieved on June 30, 2021, from https://www.abc.net.au/news/2020-05-13/coronavirus-recovery-to-push-australia-towards-gas-future/ 12239978.

Tingle, L. (2020). The Government's backing of a new power plant is a gas-fired distraction. ABC News, September 20. Retrieved on June 30, 2021, from https://www.abc.net.au/news/2020-09-19/gover nment-backing-power-plant-gas-fired-distraction/12677222.

van der Velden, J., \& White, R. (2021). The Extinction Curve: Growth and Globalisation in the Climate Endgame. Bingley, UK: Emerald Publishing Limited.

Watts, N. et al. . . Montgomery, H. (2019). The 2019 report of The Lancet Countdown on health and climate change: ensuring that the health of a child born today is not defined by a changing climate. The Lancet, 394 (10211), 1836-78. https://doi.org/10.1016/S0140-6736(19)32596-6.

Whyte, D. (2020) Ecocide: Kill the Corporation Before It Kills Us. Manchester, UK: Manchester University Press.

Publisher's Note Springer Nature remains neutral with regard to jurisdictional claims in published maps and institutional affiliations. 